\title{
Proteins regulating the intercellular transfer and function of P-glycoprotein in multidrug-resistant cancer
}

\author{
Deep Pokharel ${ }^{1}$, Ariane Roseblade ${ }^{1}$, Vici Oenarto ${ }^{1}$, Jamie F Lu' and Mary Bebawy ${ }^{1,2}$ \\ 1Discipline of Pharmacy, The Graduate School of Health, The University of Technology Sydney, Sydney, NSW 2007, Australia \\ 'Laboratory of Cancer Cell Biology and Therapeutics, The University of Technology Sydney, Sydney, NSW 2007, Australia
}

Correspondence to: Mary Bebawy. Email: mary.bebawy@uts.edu.au

\begin{abstract}
Chemotherapy is an essential part of anticancer treatment. However, the overexpression of P-glycoprotein (P-gp) and the subsequent emergence of multidrug resistance (MDR) hampers successful treatment clinically. P-gp is a multidrug efflux transporter that functions to protect cells from xenobiotics by exporting them out from the plasma membrane to the extracellular space. P-gp inhibitors have been developed in an attempt to overcome P-gp-mediated MDR; however, lack of specificity and dose limiting toxicity have limited their effectiveness clinically. Recent studies report on accessory proteins that either directly or indirectly regulate P-gp expression and function and which are necessary for the establishment of the functional phenotype in cancer cells. This review discusses the role of these proteins, some of which have been recently proposed to comprise an interactive complex, and discusses their contribution towards MDR. We also discuss the role of other pathways and proteins in regulating P-gp expression in cells. The potential for these proteins as novel therapeutic targets provides new opportunities to circumvent MDR clinically.
\end{abstract}

Keywords: cancer, extracellular vesicles, FERM, microparticles, multidrug resistance, P-glycoprotein

Published: 18/09/17

Received: 27/05/2017

ecancer 2017, 11:768 https://doi.org/10.3332/ecancer.2017.768

Copyright: (C) the authors; licensee ecancermedicalscience. This is an Open Access article distributed under the terms of the Creative Commons Attribution License (http://creativecommons.org/licenses/by/3.0), which permits unrestricted use, distribution, and reproduction in any medium, provided the original work is properly cited. 


\section{Introduction}

Multidrug resistance (MDR) is a unique type of resistance by which cancer cells develop cross resistance to a broad spectrum of anticancer agents [1]. It was first described in 1970 as "an altered qualitative difference in cell membranes that resulted in decreased permeability towards actinomycin D and other compounds" [1]. Since this observation, the pathways contributing to drug resistance have been shown to be heterogeneous, dynamic, and persist to confound cancer treatment $[1,2]$. The cellular mechanisms contributing to drug resistance are multifactorial and include the overexpression of drug efflux pumps, reduced drug uptake, activation of drug detoxifying systems, drug sequestration and altered drug targets among others [3,4]. Other prominent mechanisms, by which cancer cells resist the cytotoxic effects of chemotherapeutic drugs, include but are not limited to the following:

\section{DNA repair mechanisms}

Several mechanisms for DNA repair exist, which contribute to resistance to alkylating agents, anthracyclines and platinum compounds $[5,6]$. Revision repair by O-6-methylguanine-DNA methyltransferase (MGMT) and nucleotide excision repair are the main mechanisms associated with clinically significant resistance to methylating agents and platinum-containing agents, respectively [7]. MGMT is a protein responsible for the repair of damage to DNA caused by alkylating agents. The overexpression of MGMT in glioblastoma is associated with resistance to alkylating agents, by removing alkyl groups from the 06 position of guanine in tumour cells [8]. The methylation of the promoter region of MGMT gene suppresses MGMT expression, resulting in an improvement in the prognosis of glioma patients [9].

\section{Autophagy}

Autophagy is mediated by a unique organelle called the autophagosome [10]. This is a mechanism of cellular repair, whereby damaged cellular organelles are packaged inside vesicles and delivered to the lysosomes for degradation [11]. Lysosomal degradation results in the generation of cellular energy, which promotes cell survival following episodes of cellular stress such as exposure to chemotherapy, hypoxia or nutrient deprivation [12]. The process of autophagy involves multiple steps including the formation of a vesicular membrane, vesicle nucleation/elongation, docking/fusion of vesicles to lysosomes, and degradation/recycling of the content [13]. The induction of autophagy has been associated with resistance to various drugs, including epirubicin, bevacizumab, sorafenib, gefitinib, erlotinib, used in the treatment of breast cancer, hepatocellular carcinoma, oesophageal carcinoma, lung cancer, glioblastoma, nasopharyngeal cancer, ovarian cancer, prostate cancer, pancreatic adenocarcinoma, and lymphoma [11, 14-21].

\section{Defective apoptosis}

Apoptosis is a highly conserved process of programmed cell death, which is activated by most chemotherapeutic drugs [22], and the dysregulation of which leads to drug resistance and cell survival [7, 23-25]. p53 is a key regulator of the anti-apoptotic B-cell lymphoma 2 (Bcl-2) protein [26]. Mutations to p53 result in the loss of pro-apoptotic function of wild-type p53 and a marked increase in Bcl-2 expression $[26,27]$, resulting in cancer development, progression, and resistance to chemotherapy [28].

\section{Tumour microenvironment}

The tumour microenvironment also supports resistance to chemotherapeutic drugs. Proteins belonging to the extracellular matrix play an important role in the regulation of cell proliferation, differentiation, and metastasis [29]. For instance, the recruitment of TH2-type tumourassociated macrophages (TAMS) facilitate cancer survival through their supportive role in angiogenesis and in suppressing the CD8+ T-cell antitumour immune response [30]. Likewise the interaction between fibroblasts and cancer cells results in the expression of monocyte colony-stimulating factors, stromal cell-derived factor 1 and matrix metalloproteinases, which are associated with fibroblast-activated cancer and invasive disease [31]. Fibroblasts promote rapid growth of oestrogen receptor-positive breast cancer cells, leading to resistance to those drugs targeting oestrogen receptors, such as tamoxifen [32]. 


\section{P-glycoprotein: a member of ATP-binding cassette superfamily of membrane transporters}

Membrane transporters play a central role in the emergence of MDR and in the translocation of chemotherapeutics and other substances across the cancer cell plasma membranes. These transporters, physiologically present in most cells, are involved in the efflux of compounds such as lipids, linear, and cyclic peptides, as well as cytotoxic and non-toxic drugs [33]. ABC transporters use ATP hydrolysis to translocate substrates across the cell membrane to the cell exterior [34]. Structural characteristics typical of members of this superfamily include two cytoplasmic nucleotide-binding domains (NBD's) that contain a conserved sequence motif (the Walker A motif) for the binding and hydrolysis of ATP and two trans-membrane domains (TMD's) involved in substrate recognition and binding [35-37]. There are 49 ABC genes that are arranged in seven subfamilies of $A$ to $G[38,39]$. Currently, the most studied ABC transporters contributing to MDR in cancer are $\mathrm{P}-\mathrm{gp} / A B C B 1$ and multidrug-resistant protein 1 (MRP1/ABCC1). These transporters are inherently expressed in most normal mammalian cells and are typically localised at sites of xenobiotic exposure [40]. These transporters are found in high levels in the liver, jejunum, blood-brain barrier and kidney and play a significant role in regulating the absorption, distribution, metabolism and ultimately, elimination of xenobiotics across these pharmacological barriers [41, 42].

P-gp is a $170 \mathrm{kDa}$ protein, comprised of a single polypeptide of two homologous halves [43, 44]. Each half comprises of six TMD's with a NBD on the cytoplasmic side of a membrane [44, 45] (Figure 1). The protective role that P-gp serves in preventing xenobiotic exposure of vital organs has been validated both in studies using MDR knock-out mice and in studies using pharmacological inhibitors [45]. Malignant tumour cells effectively exploit the protective function of members of this superfamily and when hyperexpressed in malignant cells, serve to prevent the accumulation of cytotoxins within the tumour mass.

The first human ABC-transporter cloned, $\mathrm{P}$-gp ( $A B C B 1, \mathrm{MDR} 1)$ is the most extensively studied member of this superfamily and is regarded as the 'classical' ABC-transporter. First isolated from MDR Chinese hamster ovary cells, it was the first candidate associated with an intrinsic role in conferring cancer MDR [46]. The 'classical' MDR phenotype, however, was later characterised as a cross-resistance pattern towards vinca alkyloids, anthracyclines, taxanes, and epipodophyllotoxins [42, 47].

\section{Role of extracellular vesicles in transferring P-glycoprotein}

Microparticles (MPs) are small membrane extracellular vesicles typically $0.1-1 \mu \mathrm{m}$ in diameter [48]. MPs are released by various cell types and are involved in many physiological functions such as inflammation, homeostasis, coagulation, chemotherapeutic drug resistance and metastasis [2, 4, 34, 49, 50, 51-55]. MPs are established vectors for the cell-to-cell transfer of bioactive molecules including proteins and nucleic acids from their originating cell and mediate intercellular cross talk by transferring functional proteins, nucleic acids, lipids, antigens and cytokines from donor cells to recipient cells [48,55-57]. It is not surprising that malignant cells shed a significantly greater number of MP's in contrast to non-malignant cells [2,58]. Hence, in cancer patients, the number of circulating MPs as well as their cargo are considerably distinguishable from a healthy patient $[52,53]$. We were the first to discover a non-genetic pathway contributing to MDR via MP-mediated transfer of functional resistance proteins and nucleic acids from MDR cells to drug-sensitive cells [48, 55, 59] (Figure 2). Specifically, we showed that MPs were spontaneously shed from P-gp and MRP-1 overexpressed MDR leukaemic/breast cancer cells and contain significant amounts of functional resistance proteins (P-gp and MRP1), together with numerous other proteins and nucleic acids that can establish a functional MDR phenotype, increased metastatic capacity and alter the biomechanical properties of recipient cells $[47,55,56,59,60-63]$. In defining the vesicular transfer of MDR, we performed a series of experiments including proteomic profiling and comparative analysis of the MP cargo isolated from MDR and drug-sensitive breast cancer cells [62]. We observed the selective packaging of P-gp, CD44, Ezrin, Radixin, and Moesin in MDR breast cancer derived MPs together with 117 other proteins unique to the resistance cargo, which we proposed may play a role in establishing the MDR phenotype in cancer cell populations [62]. We discuss the role of some of these proteins in this context.

\section{Tubulins/microtubules}

On the basis of its primary amino acid sequence, P-gp consists of two identical domains, each comprised of six transmembrane helices with a large cytoplasmic domain containing the ATP-binding sequences (Figure 1). These two halves are linked by $\sim 90$ amino acids, termed the 
linker domain [64]. Proteins with masses of $\sim 80,57$, and $27 \mathrm{kDa}$ are known to interact with the linker domain [64]. These proteins included $\alpha$ - and $\beta$-tubulins [64], emphasising the intimate association between the cytoskeleton and P-gp. Furthermore, the phosphorylation state of P-gp plays an important role in the binding P-gp to tubulin or microtubule filaments [64].

Microtubules are important cellular components that participate in the maintenance of cell morphology and perform cellular functions such as cytokinesis, mitosis/meiosis, secretion, transmembrane signalling, and intracellular transport. Typical substrates of P-gp including vinblastine and vincristine act to destabilise microtubule formation whereas others, including paclitaxel (taxol), docetaxel, and epothilone act to stabilise [65].

Tubulin is found in high levels in drug-resistant cells [66, 67]. Specifically, paclitaxel-resistant murine cells, human lung, ovarian, prostate and breast cancer have increased expression of $\beta \mathrm{I}$-tubulin [68, 69]. A correlation between $\beta$ II-tubulin expression was reported with lower docetaxel response rates [70]. An increase in the expression of $\beta$ III-tubulin was associated with paclitaxel resistance and decreased expression was observed when cells acquired resistance to vinca alkaloids, including vinflunine [66, 71-73]. Higher levels of $\beta$ III-tubulin along with $\beta \mathrm{I}$-tubulin have also been associated with resistance to taxanes and docetaxel-based chemotherapy in various human cancers [74-76]. The knockdown of $\beta$ III-tubulin corresponds with increased sensitivity to tubulin-binding agents and increased sensitivity to DNAdamaging agents [77]. Similar results were reported by Kyu-Ho Han et al., who showed that the reduction of a-tubulin by ka1 antisense results in H460/T800 cells becoming more sensitive to the antimitotic drugs including paclitaxel, colchicine, and vinblastine [78]. This may occur through Blll-tubulin effects on increasing microtubule dynamics [79] or by rendering microtubules less sensitive to the effects of paclitaxel [80].

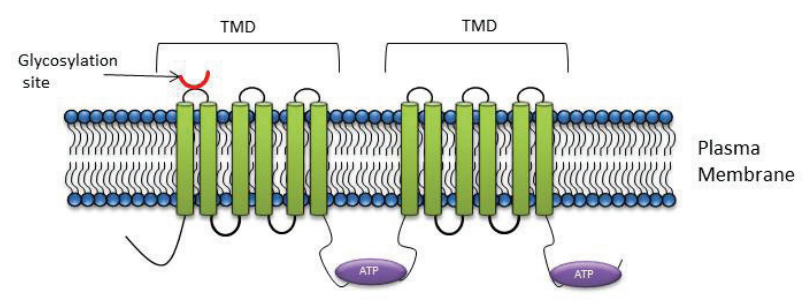

Figure 1. P-gp structure: The core structure of P-gp includes two homologous halves, each half comprising of six transmembrane domains with a nucleotide binding domain.
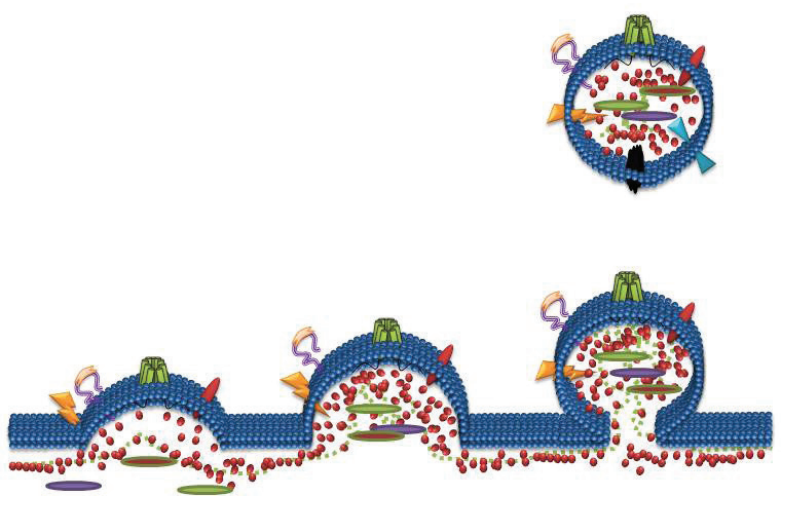

Figure 2. Formation of Microparticles (MPs): MPs are membrane vesicles released from membrane budding following loss of phospholipid asymmetry and cleavage of the underlying cytoskeleton. MPs package and transfer bioactive lipids, nucleic acids and proteins from the parental cells to recipient cells as part of cell-to-cell communication. 


\section{Ezrin, Radixin, Moesin}

A group of highly homologous proteins, Ezrin, Radixin and Moesin, collectively referred to as ERM, belong to the FERM (four-point-one band ERM) domain proteins [81]. These proteins are $\sim 300$ amino acids long, with a molecular weight of $\sim 80 \mathrm{kDa}$. ERM proteins function as cytoskeletal linkers and are involved in many cellular processes, including migration, growth and adhesion [82]. These functions are facilitated through the binding of ERM proteins directly to the C-terminal domain of actin filaments and to the cytoplasmic NH2-terminal domain of integral membrane proteins such as CD44, intercellular adhesion molecule-1 (ICAM-1), ICAM-2, and CD43 [83]. Structurally, ERM proteins comprise three domains including (1) N-terminal FERM domain, (2) central a-helical domain, and (3) C-terminal tail domain. $\mathrm{P}$-gp has been shown to bind to amino acid residues 149-242 of the N-terminal domain of Ezrin and this binding has been shown to contribute to the P-gp-mediated resistance phenotype [84, 85].

ERM proteins are essential for the stability and functionality of P-gp in normal tissues and in cancer cells [86-89]. Kobori et al., reported that anticancer substrates of P-gp activate the Ras homologue gene family member A (RhoA) and Rho-associated protein kinases (ROCK) that increases the expression of ERM, leading to an increase in P-gp expression [89]. Kano et al., investigated the functional role of ERM proteins as transcriptional regulators of P-gp following knockdown of individual proteins of the ERM family [85]. Their results showed that ezrin influences the expression of P-gp whereas Radixin reduced P-gp expression by 70\% [86]. Similar results were observed by Yang et al., in radixin and ezrin silenced Caco-2 cells, where P-gp expression was reduced in both cases [90]. Furthermore, in Caco-2 cell lines, the plasma membrane localisation of P-gp was significantly decreased after knockdown of radixin [90]. In separate experiments, radixin was reported to increase P-gp expression in the small intestine after repeated oral treatment with etoposide [91]. Moesin on the other hand has been shown to have no effect on P-gp expression, but it is often linked with increased tumour size and invasion of cancer cells [92].

\section{Hyaluronan and CD44}

Hyaluronan (HA) is a non-sulphated linear glycosaminoglycan, consisting of repeating disaccharide units of D-glucuronic acid and N-acetylD-glucosamine [93]. HA is synthesised at the plasma membrane and released immediately onto the cell surface or into the extracellular matrix [94]. HA interacts with the cell surface in at least two ways, (i) localising at the cell surface by sustained transmembrane interactions with its synthases [94] and (ii) through binding to specific cell-surface receptors such as CD44 and CD168 (RHAMM) [95]. Binding of HA to the N-terminal part of CD44 receptor is involved in resistance to chemotherapeutic drugs in many cancers [96-99]. This is believed to be mediated through effects downstream via epidermal growth factor receptor (EGFR) signalling [96], promoting c-Jun signalling [100], through the interaction with several cytoskeletal proteins [101] and RhoA signalling [101, 102]. Bourguignon et al., further validated the effect of RhoA signalling where they demonstrated that HA-induced CD44 interaction with c-Src-activated-Twist plays a major role in microRNA-10b production, leading to downregulation of tumour supressor proteins, RhoA/RhoC upregulation, activation of Rho-kinase and breast tumour cell invasion [103]. Recently, it was shown that inhibiting MDR inhibits the synthesis and secretion of HA, suggesting that HA might be secreted through efflx transporters [104]. We have also shown that vesicles from MDR cells also selectively package HA [105].

CD44 is a transmembrane cell surface glycoprotein, expressed by a large number of cell types and has a critical role in cell proliferation, differentiation, migration and adhesion [106]. The cytoplasmic region of CD44 comprises 72 amino acid residues that have been shown to interact with actin filaments through ERM proteins [107]. The N-terminus of activated ERM proteins bind to a motif between the transmembrane region and the ankyrin-binding site of CD44, and the carboxyl terminus binds to filamentous actin (F-actin), thus linking CD44 to the actin cytoskeleton [107]. P-gp and CD44 are colocalised, coregulated, and coimmunoprecipitated in MDR cells [108]. The introduction of CD44 in cells increases the expression of P-gp within the same cells and knockdown of CD44 highly affects the drug efflux mechanism of P-gp-mediated MDR [81, 108, 109]. Miletti-Gonzalez et al., showed that P-gp expression in drug-resistant cells had a positive correlation with the level of CD44 expression [110]. Our laboratory investigated the role of CD44, ezrin, radixin, and moesin in the regulation of P-gp functionality and acquisition of MDR. By sequentially silencing ERM and CD44 proteins in resistant breast cancer cells, we showed that CD44 and radixin, in particular, were required for P-gp-mediated drug efflux functionality, whereas all ERM proteins play a significant role in the vesicular transfer of functional P-gp to the recipient cells [81]. 


\section{CD147/Basigin}

Matrix metalloproteinases (MMPs) are zinc-dependent endopeptidases that are highly expressed during tumour invasion and metastasis [111]. The increased expression and activity of MMPs in MDR cancer cells is often attributed to the overexpression of CD147 (Basigin), an extracellular MMP inducer [111]. CD147 is a cell-surface glycoprotein that regulates the expression and function of both P-gp and MMPs [112]. Similar to P-gp, CD147 is highly glycosylated, which is one of the many post-translational modifications of proteins closely associated with adhesion, invasion and metastasis of tumour cells [113]. The N-glycosylation of CD147 facilitates its interaction with other proteins [113]. In addition, inhibition of N-glycosylation has been shown to increase the ubiquitination process that degrades both P-gp and CD147 [114]. CD147 is also involved in increasing resistance to P-gp drug substrates and regulates the expression of $A B C B 1, \mathrm{MMP2}$, and MMP9 via an Erk1/2-dependent signalling pathway in breast cancer cells [115]. CD147 and P-gp coimmunoprecipitate and colocalise in MCF7/Adr cells, and furthermore, after treating these cells with P-gp substrates, CD147 expression is induced [114]. Silencing CD147 gene expression increases chemosensitivity in a human ovarian cancer cell line and knockdown of CD147 in MCF7/Adr cells reduces resistance to P-gp substrate drugs $[115,116]$.

CD147 is composed of two immunoglobulin (lg) domains in the extracellular region [117], which contains three Asn-linked glycosylation sites [118]. The first Ig domain is involved in MMP induction whereas the second Ig domain is required for association with caveolin-1 [118] (Figure 3).

\section{Caveolin}

CD147 associates with caveolin (Cav), which is the structural protein of caveolae (small invagination of the plasma membrane (Figure 3)) that interact and regulate the function of a wide variety of proteins known to be involved in homoeostasis, cell proliferation, and adhesion [119]. These 20-24 kDa proteins are highly conserved with three genes expressed in mammalian cells; Cav-1, Cav-2, and Cav-3. Cav-1 and Cav-2 are overexpressed in adipocytes, endothelial cells, and fibroblasts, whereas Cav- 3 is explicitly expressed in striated muscle cells [120]. In human cells, Cav-1 has two isoforms; the $\alpha$-isoform (178 amino acids) and $\beta$-isoform (32 amino acids).

The upregulation of Cav-1 in MDR cells occurs upon short exposure to cytotoxic drugs [123, 122]. This upregulation is observed at both RNA and the protein level after $24 \mathrm{~h}$ of cytotoxin exposure [121, 122]. Similarly, P-gp localises in the caveolae of MDR cells [121] where it is colocalised with Cav-1 in many cells including CHRC5 chemoresistant cells [123], A549 lung carcinoma cells [124] and brain endothelial cells [123]. The downregulation of Cav-1 increases P-gp functionality [125]. The high expression of Cav-1 has been identified in a number of MDR cancer cells, including colchicine-resistant HT-29-MDR cells [126], vinblastine-resistant SKVLB1 ovarian carcinoma cells [121], taxol-resistant A549-T24 lung carcinoma cells [121], and adriamycin-resistant MCF-7 breast adenocarcinoma cells [127].

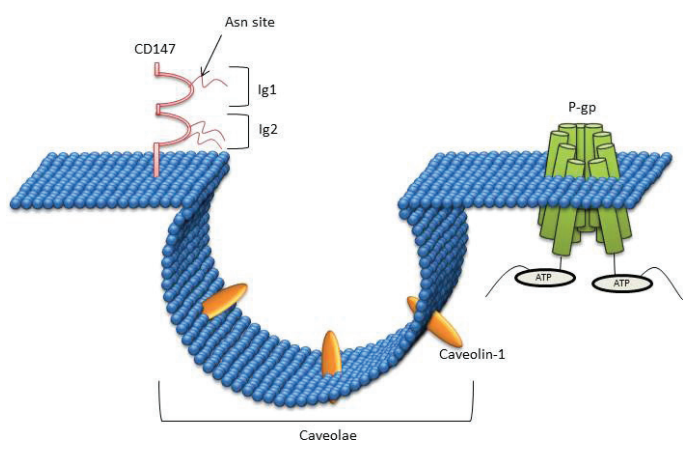

Figure 3. CD147 interaction with Caveolin-1: CD147 is comprised of two immunoglobulin (Ig) domains in the extracellular region, which contain three Asn-linked glycosylation sites. The first Ig domain is involved in MMP induction, whereas the second Ig domain is required for association with caveolin-1. 


\section{Rab-related proteins}

P-gp is primarily localised in the plasma membrane, but it is also localised intracellularly in the endoplasmic reticulum, golgi, endosome, lysosome and proteasome [127-130]. These intracellular sites are important in the synthesis, post-translational modification, traffic/recycling, and degradation of P-gp [128-131]. P-gp trafficking and recycling is performed with a group of proteins commonly known as Rab proteins [132]. Rab proteins are part of the Ras superfamily of small GTPases known to regulate most vesicular transport events by regulating vesicle docking and fusion [133, 134]. There are more than 60 Rab proteins in mammalian cells and most of them are localised in the subcellular membrane compartment, where they control the intracellular trafficking routes of proteins and lipids [135, 136]. These proteins are often associated with P-gp. Involvement of Rab6 is observed during the trafficking of P-gp from Golgi to the plasma membrane [132], whereas Rab11 and Rab13 are involved in the trafficking of P-gp from Golgi to the recycling endosome [137, 138] and Rab11a has been shown to be involved in the trafficking P-gp to the apical membrane in polarised cells [139]. The overexpression of Rab4 in MDR cells is associated with an increase in drug sensitivity through Rab4-mediated localisation of P-gp in cytosolic endosomal compartments [140]. Rab4 along with Rab14 are involved in membrane protein trafficking and interact with the C-terminal of P-gp [140]. Rab4 co-localises with P-gp in the cytoplasmic compartments [140]. Similar results were observed with the overexpression of Rab6c protein, which resulted in the intracellular localisation of P-gp and increased accumulation of anticancer drugs [141]. Similarly, transfection of dominant negative Rab5 increased the intracellular localisation of P-gp by 9 -fold and consequently increases the intracellular accumulation of daunorubicin. These studies support strategies for the circumvention of MDR through the regulation of subcellular redistribution of P-gp [142]. Table 1 summarises the role of Rab proteins in cancer.

Table 1. Rab-related proteins in cancer.

\begin{tabular}{|c|l|l|c|}
\hline & \multicolumn{1}{|c|}{ Name } & \multicolumn{1}{|c|}{ Function in cancer } & References \\
\hline 1 & $\begin{array}{l}\text { Rab1b, Rab4b, Rab10, } \\
\text { Rab22a, Rab24 }\end{array}$ & $\begin{array}{l}\text { Overexpressed in hepatocellular } \\
\text { carcinoma }\end{array}$ & {$[172]$} \\
\hline 3 & Rab1a & $\begin{array}{l}\text { Overexpressed in tongue } \\
\text { squamous cell carcinoma }\end{array}$ & {$[173]$} \\
\hline 4 & Rab2 & $\begin{array}{l}\text { Overexpressed in peripheral } \\
\text { blood mononuclear cells from } \\
\text { patients with solid tumour }\end{array}$ & {$[174]$} \\
\hline 5 & Rab3B & $\begin{array}{l}\text { Associated with lung tumour } \\
\text { progression in mouse }\end{array}$ & {$[176]$} \\
\hline 6 & Rab20 & $\begin{array}{l}\text { Upregulated in prostate cancer } \\
\text { and promotes cancer cell survival }\end{array}$ & {$[177]$} \\
\hline 7 & Rab31 & $\begin{array}{l}\text { Overexpressed in exocrine } \\
\text { pancreatic carcinoma }\end{array}$ & {$[178]$} \\
\hline 8 & Rab25 & $\begin{array}{l}\text { Associated with } \\
\text { Breast cancer patients }\end{array}$ & {$[179]$} \\
\hline 9 & Rab8 & $\begin{array}{l}\text { Overexpressed in breast cancer } \\
\text { and ovarian cancer and associated } \\
\text { with decreased survival }\end{array}$ & $\begin{array}{l}\text { Mediates exocytosis of matrix } \\
\text { metalloprotease involved in cell } \\
\text { invasion }\end{array}$ \\
\hline
\end{tabular}




\section{Ubiquitination}

Ubiquitination is a process that regulates P-gp expression. It is a reaction where ubiquitin molecules are covalently ligated to substrate proteins via isopeptide bonds formed through the C-terminal glycine to the $\varepsilon$-amino group of lysine residues [143]. This reaction plays an important role in cell-surface signalling as well as in endocytosis and degradation of ATP-binding cassette transporters [144, 145]. Ubiquitin consists of a conserved 76-amino acid polypeptide and the conjugation of ubiquitin to substrates is a three step process involving: activation by ubiquitin-activating enzyme (E1), conjugation by ubiquitin-conjugating enzymes (E2) and ligation by ubiquitin-ligase enzyme (E3) [146].

Several transcription factors including c-Jun, FOXO3a, the vitamin D receptor and nuclear factor-kB (NF-kB) are involved in the transcription of $A B C B 1$ [147-150]. These transcription factors are regulated by ubiquitination, highlighting the association between ubiquitin and drug resistance. For example, ubiquitin promotes the binding of c-Jun to the activator protein-1 (AP-1) site of the $A B C B 1$ promoter to reduce transcription [149]. FBXO15/FBX15 (F-box proteins and a part of the Skp1-Cullin1-FBXO15 ubiquitin E3 ligase complex) and Ube2rl/ Cdc34/Ubc3 (E2 enzymes) regulate P-gp expression through effects on the ubiquitin-proteasome pathway [131]. Similarly, the activation of JNK pathway via E3 ubiquitin ligase downregulates P-gp transcription [151]. Recent studies have also shown that inhibition of the PI3K/ Akt-signalling pathway can lead to decreased cell growth, tumour formation, and reverse P-gp-mediated MDR [61]. Interestingly, a casitas B-lineage lymphoma-b (Cbl-b) protein, which is a member of the E3 ubiquitin ligase family, interacts with the p53-regulatory subunit of PI3K and results in PI3K ubiquitination and degradation [152]. Nonetheless, transfection of MDR cells with wild-type ubiquitin or treatment with an N-glycosylation inhibitor increases the ubiquitination of P-gp and increases P-gp degradation [143, 144].

\section{Heat-shock proteins}

Heat-shock proteins (Hsps) are molecular chaperones that facilitate folding of newly synthesised polypeptides, stabilisation, refolding and protein trafficking [154] and are involved in regulating P-gp expression. They are classified based on their molecular weights: hsp100, 90, $70,60,40$ and 'small hsps' [154]. Hsp proteins such as 27, 40, and 70 play an important role in the cell before the unfolded protein reaches the hsp90 [155]. These Hsp proteins facilitate rapid cell division, metastasis, and evasion of apoptosis in cancer cells [154]. They are generally expressed in all cell types, but their synthesis increases during times of cellular, chemical and physical stress, and during exposure to anticancer drugs [154].

Hsp 90 has emerged as a major therapeutic target for cancer therapy because of its ability to bind and stabilise a broad range of proteins [156]. The inhibitor of Hsp90 together with an inhibitor of Sirtuin-1 inhibit the growth of chemoresistant cells isolated from human chronic myeloid leukaemia K562 cells [157]. Similarly, inhibition of Hsp90 leads to the prolonged inhibition of Akt signalling, inactivates NF-KB and eventually causes resistance to chemotherapeutics and molecularly targeted drugs [158]. Nonetheless, activated HSP70 and NF-KB in drug-resistant A549/DOX cells modulate P-gp expression resulting in doxorubicin retention and enhanced apoptosis [159].

\section{Glutathione S-transferase}

Glutathione s-transferase (GST) is a superfamily of dimeric proteins catalysing the conjugation of glutathione with a wide variety of electrophiles [160]. GSTs are involved in development of drug resistance to chemotherapy through direct detoxification and by inhibiting the mitogen-activated protein kinase (MAPK) pathway [161]. According to their amino acid sequences, these families are divided into four multigene classes, $\alpha, \mu, \pi, \theta$ (Cullen et al., 2003). GST-m located on chromosome 11q13, plays an important role in the detoxification of xenobiotics through conjugation to glutathione [162]. It is often related with MDR because of its characteristic to catalyse the conjugation of glutathione and anticancer drugs and then expel them from cells via GSH-conjugated export pumps [163]. GST- $\pi$ is expressed at low levels in the placenta, lung, liver, kidney, and red blood cells [164], has been shown to correlate with prognosis and is associated with MDR $[165,166]$. The coexpression of P-gp and GST- $\pi$ was shown to be $93 \%$ in patients with leukaemia and $80 \%$ in patients with lung cancer [167]. Similar results were reported by another group where high levels of GST-ח significantly contributed to clinical cisplatin resistance in different types of human cancers [168]. 


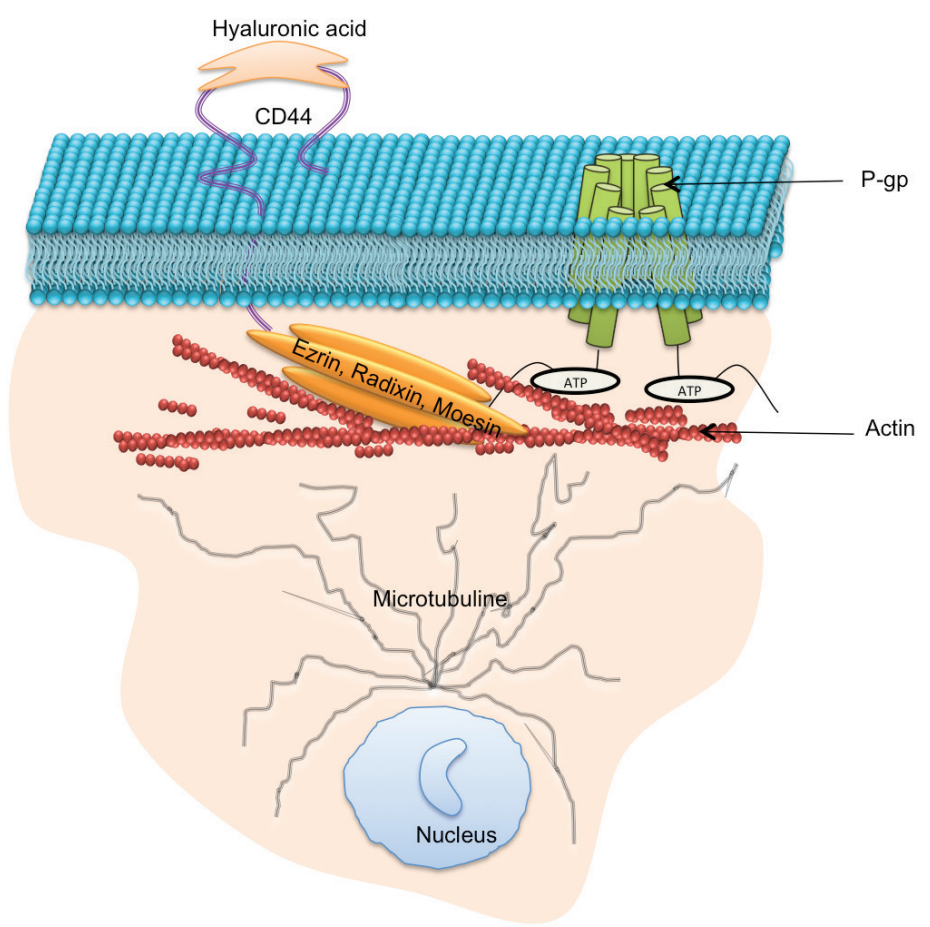

Figure 4. Protein-protein interactions which support P-gp drug efflux function: P-gp drug efflux function and intercellular transfer has been shown to to be regulated by a number proteins including microtubule, ezrin, radixin, moesin, and CD44.

\section{Discussion and conclusions}

For more than three decades, researchers have searched for effective ways to inhibit P-gp as a way of circumventing MDR in cancer [169]. There are currently four generations of P-gp inhibitors, and few of them have reached clinical trial [170]. These inhibitors have been limited by low binding affinities towards P-gp, requiring their use at high doses and hence resulting in dose-limiting toxicity [159]. P-gp is expressed in numerous cells and tissues where it functions to efflux potentially harmful xenobiotics preventing their accumulation within specialised tissues [171]. The current inhibitor molecules are non-selective and target both the overexpressed P-gp in tumour cells and the endogenous $\mathrm{P}-\mathrm{gp}$, resulting in altered pharmacokinetic profiles and increasing risk of drug toxicity. Hence, an alternative approach is required to overcome P-gp-mediated MDR that supports the accumulation of chemotherapeutics drugs within the tumour mass while not compromising the inherent defence mechanism of normal cells. There is much evidence supporting the theory that drug efflux is not solely dependent on P-gp itself but also on proteins it interacts with or which regulate its expression (Figure 4). Our laboratory has previously used gene-silencing strategies targeting ezrin, radixin, moesin and CD44 proteins [81] and observed that CD44 and radixin reduce P-gp functionality to the greatest extent. We also reported that the vesicular transfer and acquisition of P-gp in recipient cell membranes was regulated by the presence of ezrin and moesin. These results demonstrate the tight association between this group of proteins with P-gp and strengthen opportunities for alternative approaches in overcoming MDR. This paper describes numerous proteins that are involved in regulating P-gp-mediated MDR, either directly or indirectly and introduces novel strategies to overcome cancer drug resistance, which can be considered further.

\section{References}

1. Biedler JL, Riehm H (1970) Cellular resistance to actinomycin D in Chinese hamster cells in vitro: cross-resistance, radioautographic, and cytogenetic studies Cancer Res 30 1174-1184 PMID: 5533992

2. Roseblade A, Luk F, and Ung A et al (2015) Targeting microparticle biogenesis: a novel approach to the circumvention of cancer multidrug resistance Curr Cancer Drug Targets 15 205-214 https://doi.org/10.2174/1568009615666150225121508 PMID: 25714701 
3. Gottesman MM, Fojo T, Bates SE (2002) Multidrug resistance in cancer: role of ATP-dependent transporters Nat Rev Cancer 2 48-58 https://doi.org/10.1038/nrc706 PMID: 11902585

4. Gong J, Jaiswal R, and Dalla P, et al (2015) Microparticles in cancer: a review of recent developments and the potential for clinical application Paper presented at: Seminars in cell \& developmental biology (Elsevier)

5. Xu Z, Chen ZP, and Malapetsa A, et al (2002) DNA repair protein levels vis-a-vis anticancer drug resistance in the human tumor cell lines of the National Cancer Institute drug screening program Anti-cancer Drug 13 511-519 https://doi.org/10.1097/00001813$\underline{200206000-00010}$

6. Helleday T, Petermann E, and Lundin C, et al (2008) DNA repair pathways as targets for cancer therapy Nature Rev Cancer 8193 https://doi.org/10.1038/nrc2342

7. Lage H (2008) An overview of cancer multidrug resistance: a still unsolved problem Cell Mol Life Sci 65 3145-3167 https://doi. org/10.1007/s00018-008-8111-5 PMID: 18581055

8. Hegi ME, Liu L, and Herman JG, et al (2008) Correlation of O6-methylguanine methyltransferase (MGMT) promoter methylation with clinical outcomes in glioblastoma and clinical strategies to modulate MGMT activity J Clin Oncol 26 4189-4199 https://doi. org/10.1200/JC0.2007.11.5964 PMID: 18757334

9. Oberstadt MC, Bien-Möller S, and Weitmann K, et al (2013) Epigenetic modulation of the drug resistance genes MGMT, ABCB1 and ABCG2 in glioblastoma multiforme BMC Cancer 13617 https://doi.org/10.1186/1471-2407-13-617

10. Xie CM, Chan WY, and Yu S, et al (2011) Bufalin induces autophagy-mediated cell death in human colon cancer cells through reactive oxygen species generation and JNK activation Free Radic Biol Med 51 1365-1375 https://doi.org/10.1016/j.freeradbiomed.2011.06.016 PMID: $\underline{21763418}$

11. Sui $X$, Chen R, and Wang Z, et al (2013) Autophagy and chemotherapy resistance: a promising therapeutic target for cancer treatment Cell Death Dis 4 e838 https://doi.org/10.1038/cddis.2013.350 PMID: 24113172 PMCID: 3824660

12. Sun WL, Chen J, and Wang YP, et al (2011) Autophagy protects breast cancer cells from epirubicin-induced apoptosis and facilitates epirubicin-resistance development Autophagy 7 1035-1044 https://doi.org/10.4161/auto.7.9.16521 PMID: 21646864

13. Chen Y, Fu L, and Wen X, et al (2014) Oncogenic and tumor suppressive roles of microRNAs in apoptosis and autophagy Apoptosis 19 1177-1189 https://doi.org/10.1007/s10495-014-0999-7 PMID: 24850099

14. Liu D, Yang Y, and Liu Q, et al (2011) Inhibition of autophagy by 3-MA potentiates cisplatin-induced apoptosis in esophageal squamous cell carcinoma cells Med Oncol 28 105-111 https://doi.org/10.1007/s12032-009-9397-3

15. Mirzoeva OK, Hann B, and Hom YK, et al (2011) Autophagy suppression promotes apoptotic cell death in response to inhibition of the PI3K-mTOR pathway in pancreatic adenocarcinoma J Mol Med 89 877-889 https://doi.org/10.1007/s00109-011-0774-y

16. Hu YL, DeLay M, and Jahangiri A, et al (2012) Hypoxia-induced autophagy promotes tumor cell survival and adaptation to antiangiogenic treatment in glioblastoma Cancer Res 72 1773-1783 https://doi.org/10.1158/0008-5472.CAN-11-3831 PMID: 22447568 PMCID: $\underline{3319869}$

17. Rosich L, Xargay-Torrent S, and López-Guerra M, et al (2012) Counteracting autophagy overcomes resistance to everolimus in mantle cell lymphoma Clin Cancer Res 18 5278-5289 https://doi.org/10.1158/1078-0432.CCR-12-0351 PMID: 22879389

18. Shin SW, Kim SY, and Park JW (2012) Autophagy inhibition enhances ursolic acid-induced apoptosis in PC3 cells Biochimica et Biophysica Acta 1823 451-457 https://doi.org/10.1016/j.bbamcr.2011.10.014

19. Zhang $Y$, Cheng $Y$, and Ren $X$, et al (2012) NAC1 modulates sensitivity of ovarian cancer cells to cisplatin by altering the HMGB1-mediated autophagic response Oncogene 31 1055-1064 https://doi.org/10.1038/onc.2011.290

20. Guo XI, Li D, and Sun K, et al (2013) Inhibition of autophagy enhances anticancer effects of bevacizumab in hepatocarcinoma J Mol Med 91 473-483 https://doi.org/10.1007/s00109-012-0966-0 PMCID: 3611041 
21. Song L, Liu H, and Ma L, et al (2013) Inhibition of autophagy by 3MA enhances endoplasmic reticulum stressinduced apoptosis in human nasopharyngeal carcinoma cells Oncol Lett 6 1031-1038 PMID: 24137459 PMCID: $\underline{3796402}$

22. Johnstone RW, Ruefli AA, Lowe SW (2002) Apoptosis: a link between cancer genetics and chemotherapy Cell 108 153-164 https://doi.org/10.1016/S0092-8674(02)00625-6 PMID: 11832206

23. Gottesman MM (2002) Mechanisms of cancer drug resistance Ann Rev Med 53 615-627 https://doi.org/10.1146/annurev. med.53.082901.103929 PMID: 11818492

24. Luqmani $Y$ (2005) Mechanisms of drug resistance in cancer chemotherapy Med Princ Pract 14 35-48 https://doi.org/10.1159/000086183 PMID: 16103712

25. Niero EL, Rocha-Sales B, and Lauand C, et al (2014) The multiple facets of drug resistance: one history, different approaches J Exp Clin Cancer Res 3337 https://doi.org/10.1186/1756-9966-33-37 PMID: 24775603 PMCID: 4041145

26. Nakazawa K, Dashzeveg N, and Yoshida K (2014) Tumor suppressor p53 induces miR-1915 processing to inhibit Bcl-2 in the apoptotic response to DNA damage FEBS J 281 2937-2944 https://doi.org/10.1111/febs.12831 PMID: 24814047

27. Muller PA, Vousden KH (2014) Mutant p53 in cancer: new functions and therapeutic opportunities Cancer Cell $25304-317$ https://doi.org/10.1016/j.ccr.2014.01.021 PMID: 24651012 PMCID: 3970583

28. Xu K, Liang X, and Cui D, et al (2013) miR-1915 inhibits Bcl-2 to modulate multidrug resistance by increasing drug-sensitivity in human colorectal carcinoma cells Mol Carcinog 52 70-78 https://doi.org/10.1002/mc. 21832

29. Swartz MA, lida N, and Roberts EW, et al (2012) Tumor microenvironment complexity: emerging roles in cancer therapy Cancer Res 72 2473-2480 https://doi.org/10.1158/0008-5472.CAN-12-0122 PMID: 22414581 PMCID: 3653596

30. DeNardo DG, Brennan DJ, and Rexhepaj E, et al (2011) Leukocyte complexity predicts breast cancer survival and functionally regulates response to chemotherapy Cancer Discov 1 54-67 https://doi.org/10.1158/2159-8274.CD-10-0028 PMID: 22039576 PMCID: $\underline{3203524}$

31. Li, L., Dragulev, B., Zigrino, P., Mauch, C., and Fox, J.W. (2009). The invasive potential of human melanoma cell lines correlates with their ability to alter fibroblast gene expression in vitro and the stromal microenvironment in vivo. International Journal of Cancer 125, 1796-1804.

32. Holton SE, Bergamaschi A, and Katzenellenbogen BS et al (2014) Integration of molecular profiling and chemical imaging to elucidate fibroblast-microenvironment impact on cancer cell phenotype and endocrine resistance in breast cancer

33. Li Q, Shu Y (2014) Role of solute carriers in response to anticancer drugs Mol Cell Ther 215 https://doi.org/10.1186/2052-84262-15 PMID: 26056583 PMCID: $\underline{4452062}$

34. Lu JF, Pokharel D, Bebawy M (2015) MRP1 and its role in anticancer drug resistance Drug Metab Rev 1-14

35. Ambudkar SV, Kim IW, and Xia D et al (2006) The A-loop, a novel conserved aromatic acid subdomain upstream of the Walker A motif in ABC transporters, is critical for ATP binding FEBS Lett $\mathbf{5 8 0}$ 1049-1055 https://doi.org/10.1016/j.febslet.2005.12.051 PMID: $\underline{16412422}$

36. Callaghan R, Luk F, Bebawy M (2014) Inhibition of the multidrug resistance P-glycoprotein: time for a change of strategy? Drug Metab Dispos 42 623-631 https://doi.org/10.1124/dmd.113.056176 PMID: 24492893 PMCID: 3965902

37. Vasiliou V, Vasiliou K, Nebert DW (2009) Human ATP-binding cassette (ABC) transporter family Hum Genomics 3281 https://doi. org/10.1186/1479-7364-3-3-281 PMID: 19403462 PMCID: 2752038

38. Chen Z, Shi T, and Zhang L, et al (2016) Mammalian drug efflux transporters of the ATP binding cassette (ABC) family in multidrug resistance: a review of the past decade Cancer Lett 370 153-164 https://doi.org/10.1016/j.canlet.2015.10.010 
39. Dutheil F, Dauchy S, and Diry M, et al (2009) Xenobiotic-metabolizing enzymes and transporters in the normal human brain: regional and cellular mapping as a basis for putative roles in cerebral function Drug Metab Dispos 37 1528-1538 https://doi. org/10.1124/dmd.109.027011 PMID: 19359404

40. Szakacs G, Varadi A, and Özvegy-Laczka C, et al (2008) The role of ABC transporters in drug absorption, distribution, metabolism, excretion and toxicity (ADME-Tox) Drug Discov Today 13 379-393 https://doi.org/10.1016/j.drudis.2007.12.010

41. Bebawy M, Chetty M (2009) Gender differences in p-glycoprotein expression and function: effects on drug disposition and outcome Curr Drug Metab 10 322-328 https://doi.org/10.2174/138920009788498996 PMID: 19519340

42. Bebawy M, Morris M, Roufogalis B (2001) Selective modulation of P-glycoprotein-mediated drug resistance Br J Cancer 851998 https://doi.org/10.1054/bjoc.2001.2184 PMID: 11747345 PMCID: 2364021

43. Rosenberg MF, Kamis AB, and Callaghan R, et al (2003) Three-dimensional structures of the mammalian multidrug resistance P-glycoprotein demonstrate major conformational changes in the transmembrane domains upon nucleotide binding $\mathrm{J} \mathrm{Biol}$ Chem 278 8294-8299 https://doi.org/10.1074/jbc.M211758200

44. Rosenberg MF, Callaghan R, and Ford RC, et al (1997) Structure of the multidrug resistance P-glycoprotein to $2.5 \mathrm{~nm}$ resolution determined by electron microscopy and image analysis J Biol Chem 272 10685-10694 https://doi.org/10.1074/jbc.272.16.10685 PMID: 9099718

45. Schinkel AH, Mayer U, and Wagenaar E, et al (1997) Normal viability and altered pharmacokinetics in mice lacking mdr1-type (drug-transporting) P-glycoproteins Proc Natl Acad Sci 94 4028-4033 https://doi.org/10.1073/pnas.94.8.4028

46. Juliano RL, Ling V (1976) A surface glycoprotein modulating drug permeability in Chinese hamster ovary cell mutants Biochimica et Biophysica Acta 455 152-162 https://doi.org/10.1016/0005-2736(76)90160-7 PMID: 990323

47. Whitehouse D, Rapley R (2012) Molecular and Cellular Therapeutics (John Wiley \& Sons)

48. Gong J, Luk F, and Jaiswal R, et al (2013) Microparticle drug sequestration provides a parallel pathway in the acquisition of cancer drug resistance Eur J Pharmacol 721 116-125 https://doi.org/10.1016/j.ejphar.2013.09.044 PMID: 24095666

49. Combes V, Coltel N, and Alibert M, et al (2005) ABCA1 gene deletion protects against cerebral malaria: potential pathogenic role of microparticles in neuropathology Am J Pathol 166 295-302 https://doi.org/10.1016/S0002-9440(10)62253-5 PMID: 15632021 PMCID: 1602289

50. Coltel N, Combes V, and Wassmer SC, et al (2006) Cell vesiculation and immunopathology: implications in cerebral malaria Microb Infect 8 2305-2316 https://doi.org/10.1016/j.micinf.2006.04.006

51. Bebawy M, Roseblade A, and Luk F, et al (2013) Cell-derived microparticles: new targets in the therapeutic management of disease J Pharm Pharm Sci 16 238-253 https://doi.org/10.18433/J3989X PMID: 23958193

52. Krishnan SR, Jaiswal R, and Brown RD, et al (2016a) Multiple myeloma and persistence of drug resistance in the age of novel drugs (Review) Int J Oncol 49 33-50

53. Krishnan SR, Luk F, and Brown RD, et al (2016b) Isolation of human CD138+ microparticles from the plasma of patients with multiple myeloma Neoplasia 18 25-32 https://doi.org/10.1016/j.neo.2015.11.011

54. Lu JF, Pokharel D, Bebawy M (2016a) A novel mechanism governing the transcriptional regulation of ABC transporters in MDR cancer cells Drug Deliv Transl Res 7 1-10

55. Lu JF, Pokharel D, and Padula MP et al (2016b) A novel method to detect translation of membrane proteins following microvesicle intercellular transfer of nucleic acids J Biochem mvw033 $160 \mathrm{https} / / / \mathrm{doi} .0 \mathrm{rg} / 10.1093 / \mathrm{jb} / \mathrm{mvw033}$

56. Bebawy M, Combes V, and Lee E, et al (2009a) Membrane microparticles mediate transfer of P-glycoprotein to drug sensitive cancer cells Leukemia 23 1643-1649 https://doi.org/10.1038/leu.2009.76 
57. Jaiswal R, Luk F, and Gong J, et al (2012) Microparticle conferred microRNA profiles-implications in the transfer and dominance of cancer traits Mol Cancer 1137 https://doi.org/10.1186/1476-4598-11-37

58. Mallat Z, Hugel B, and Ohan J, et al (1999) Shed membrane microparticles with procoagulant potential in human atherosclerotic plaques a role for apoptosis in plaque thrombogenicity Circulation 99 348-353 https://doi.org/10.1161/01.CIR.99.3.348 PMID: $\underline{9918520}$

59. Bebawy M, Combes V, and Lee E, et al (2009b) Membrane microparticles mediate transfer of P-glycoprotein to drug sensitive cancer cells Leukemia 23 1643-1649 https://doi.org/10.1038/leu.2009.76

60. Gong J, Jaiswal R, and Mathys JM, et al (2012) Microparticles and their emerging role in cancer multidrug resistance Cancer Treat Rev 38 226-234 https://doi.org/10.1016/j.ctrv.2011.06.005

61. Gong J, Luk F, and Jaiswal R, et al (2014) Microparticles mediate the intercellular regulation of microRNA-503 and proline-rich tyrosine kinase 2 to alter the migration and invasion capacity of breast cancer cells Front Oncol 4220 https://doi.org/10.3389/ fonc.2014.00220 PMID: 25177548 PMCID: 4133752

62. Pokharel D, Padula MP, and Lu JF, et al (2014) Proteome analysis of multidrug-resistant, breast cancer-derived microparticles J Extracell Vesicles 3 24384-24397 https://doi.org/10.3402/jev.v3.24384 PMID: 25206959 PMCID: 4142226

63. Pokharel D, Wijesinghe P, and Oenarto V, et al (2016b) Deciphering cell-to-cell communication in acquisition of cancer traits: extracellular membrane vesicles are regulators of tissue biomechanics OMICS 20 462-469 https://doi.org/10.1089/omi.2016.0072

64. Georges E (2007) The P-glycoprotein (ABCB1) linker domain encodes high-affinity binding sequences to $\alpha$-and $\beta$-tubulins Biochemistry 46 7337-7342 https://doi.org/10.1021/bi7006228 PMID: 17530867

65. Rowinsky EK, Cazenave LA, and Donehower RC (1990) Taxol: a novel investigational antimicrotubule agent $J$ Natl Cancer Inst 82 1247-1259 https://doi.org/10.1093/jnci/82.15.1247 PMID: 1973737

66. Orr GA, Verdier-Pinard $\mathrm{P}$, and McDaid $\mathrm{H}$, et al (2003) Mechanisms of taxol resistance related to microtubules Oncogene 22 7280-7295 https://doi.org/10.1038/sj.onc.1206934 PMID: 14576838 PMCID: 4039039

67. Poruchynsky MS, Kim JH, and Nogales E, et al (2004) Tumor cells resistant to a microtubule-depolymerizing hemiasterlin analogue, HTI-286, have mutations in $\alpha$-or $\beta$-tubulin and increased microtubule stability Biochemistry 43 13944-13954 https://doi. org/10.1021/bi049300+ PMID: 15518543

68. Ranganathan S, Benetatos $C$, and Colarusso $\mathrm{P}$, et al (1998) Altered beta-tubulin isotype expression in paclitaxel-resistant human prostate carcinoma cells Br J Cancer 77562 https://doi.org/10.1038/bjc.1998.91 PMID: $\underline{9484812}$ PMCID: 2149944

69. Kavallaris M, Burkhart $C$, and Horwitz S (1999) Antisense oligonucleotides to class III $\beta$-tubulin sensitize drug-resistant cells to Taxol Br J Cancer 801020 https://doi.org/10.1038/sj.bjc.6690507 PMID: 10362110 PMCID: 2363042

70. Bernard-Marty C, Treilleux I, and Dumontet C, et al (2002) Microtubule-associated parameters as predictive markers of docetaxel activity in advanced breast cancer patients: results of a pilot study Clin Breast Cancer 3 341-345 https://doi.org/10.3816/ CBC.2002.n.037

71. Burkhart CA, Kavallaris M, and Horwitz SB (2001) The role of $\beta$-tubulin isotypes in resistance to antimitotic drugs Biochimica et Biophysica Acta 1471 1-9

72. Dumontet $\mathrm{C}$, Isaac $\mathrm{S}$, and Souquet $\mathrm{PJ}$, et al (2005) Expression of class III $\beta$ tubulin in non-small cell lung cancer is correlated with resistance to taxane chemotherapy Bull Cancer 92 10025-10030

73. Estève MA, Carré M, and Bourgarel-Rey V, et al (2006) Bcl-2 down-regulation and tubulin subtype composition are involved in resistance of ovarian cancer cells to vinflunine Mol Cancer Ther 5 2824-2833 https://doi.org/10.1158/1535-7163.MCT-06-0277 PMID: $\underline{17121929}$ 
74. Mozzetti S, Ferlini C, and Concolino P, et al (2005) Class III $\beta$-tubulin overexpression is a prominent mechanism of paclitaxel resistance in ovarian cancer patients Clin Cancer Res 11 298-305 PMID: 15671559

75. Noguchi S (2006) Predictive factors for response to docetaxel in human breast cancers Cancer Sci $97813-820$ https://doi. org/10.1111/j.1349-7006.2006.00265.x PMID: $\underline{16805818}$

76. Pusztai L (2007) Markers predicting clinical benefit in breast cancer from microtubule-targeting agents Ann Oncol 18 xii15-xii20 https://doi.org/10.1093/annonc/mdm534

77. Gan PP, Pasquier E, Kavallaris M (2007) Class III $\beta$-tubulin mediates sensitivity to chemotherapeutic drugs in non-small cell lung cancer Cancer Res 67 9356-9363 https://doi.org/10.1158/0008-5472.CAN-07-0509 PMID: 17909044

78. Han EKH, Gehrke L, and Tahir S, et al (2000) Modulation of drug resistance by a-tubulin in paclitaxel-resistant human lung cancer cell lines Eur J Cancer 36 1565-1571 https://doi.org/10.1016/S0959-8049(00)00145-3 PMID: 10930805

79. Goncalves A, Braguer D, and Kamath K, et al (2001) Resistance to taxol in lung cancer cells associated with increased microtubule dynamics Proc Natl Acad Sci 98 11737-11742 https://doi.org/10.1073/pnas.191388598 PMID: 11562465 PMCID: $\underline{58799}$

80. Kamath K, Wilson L, and Cabral F, et al (2005) Blll-tubulin induces paclitaxel resistance in association with reduced effects on microtubule dynamic instability J Biol Chem 280 12902-12907 https://doi.org/10.1074/jbc.M4144777200 PMID: 15695826

81. Pokharel D, Padula MP, and Lu JF, et al (2016a) The role of CD44 and ERM proteins in expression and functionality of P-glycoprotein in breast cancer cells Molecules 21290 https://doi.org/10.3390/molecules21030290

82. Clucas J, Valderrama F (2014) ERM proteins in cancer progression J Cell Sci 127 267-275 https://doi.org/10.1242/jcs.133108

83. Barreiro O, Yáñez-Mó M, and Serrador JM, et al (2002) Dynamic interaction of VCAM-1 and ICAM-1 with moesin and ezrin in a novel endothelial docking structure for adherent leukocytes J Cell Biol 157 1233-1245 https://doi.org/10.1083/jcb.200112126 PMID: 12082081 PMCID: 2173557

84. Luciani F, Molinari A, and Lozupone F, et al (2002) P-glycoprotein-actin association through ERM family proteins: a role in P-glycoprotein function in human cells of lymphoid origin Blood 99 641-648 https://doi.org/10.1182/blood.V99.2.641 PMID: 11781249

85. Brambilla D, Zamboni S, and Federici C, et al (2012) P-glycoprotein binds to ezrin at amino acid residues 149-242 in the FERM domain and plays a key role in the multidrug resistance of human osteosarcoma Int J Cancer $1302824-2834$ https://doi. org/10.1002/ijc.26285

86. Kano T, Wada S, and Morimoto K, et al (2011) Effect of knockdown of ezrin, radixin, and moesin on P-glycoprotein function in HepG2 cells J Pharm Sci 100 5308-5314 https://doi.org/10.1002/jps.22718 PMID: 21837648

87. Zhang $Y$, Dong J, and Zhu X et al (2011) The effect of sphingomyelin synthase 2 (SMS2) deficiency on the expression of drug transporters in mouse brain Biochem Pharmacol 82 287-294 https://doi.org/10.1016/j.bcp.2011.04.009 PMID: 21554861

88. Zhang L, Xiao R, and Xiong J, et al (2013) Activated ERM protein plays a critical role in drug resistance of MOLT4 cells induced by CCL25 PLoS One 8 e52384 https://doi.org/10.1371/journal.pone.0052384 PMID: 23326330 PMCID: 3541277

89. Kobori T, Harada S, and Nakamoto K, et al (2013a) Activation of ERM-family proteins via RhoA-ROCK signaling increases intestinal P-gp expression and leads to attenuation of oral morphine analgesia J Pharm Sci 102 1095-1105 https://doi.org/10.1002/ jps. 23441

90. Yang Q, Onuki R, and Nakai C, et al (2007) Ezrin and radixin both regulate the apical membrane localization of ABCC2 (MRP2) in human intestinal epithelial Caco-2 cells Exp Cell Res 313 3517-3525 https://doi.org/10.1016/i.yexcr.2007.07.033

91. Kobori T, Harada S, and Nakamoto K, et al (2013b) Radixin influences the changes in the small intestinal p-glycoprotein by etoposide treatment Biol Pharm Bull 36 1822-1828 https://doi.org/10.1248/bpb.b13-00511 
92. Kobayashi $\mathrm{H}$, Sagara J, and Kurita $\mathrm{H}$, et al (2004) Clinical significance of cellular distribution of moesin in patients with oral squamous cell carcinoma Clin Cancer Res 10 572-580 https://doi.org/10.1158/1078-0432.CCR-1323-03 PMID: 14760079

93. Laurent TC, Fraser J (1992) Hyaluronan FASEB J 6 2397-2404 PMID: 1563592

94. Toole BP (2004) Hyaluronan: from extracellular glue to pericellular cue Nat Rev Cancer 4 528-539 https://doi.org/10.1038/nrc1391 PMID: 15229478

95. Turley EA, Noble PW, and Bourguignon LY (2002) Signaling properties of hyaluronan receptors J Biol Chem 277 4589-4592 https://doi.org/10.1074/jbc.R100038200

96. Wang SJ, Bourguignon LY (2006) Hyaluronan and the interaction between CD44 and epidermal growth factor receptor in oncogenic signaling and chemotherapy resistance in head and neck cancer Arch Otolaryngol Head Neck Surg 132 771-778 https:// doi.org/10.1001/archotol.132.7.771 PMID: 16847188

97. Ohashi R, Takahashi F, and Cui R, et al (2007) Interaction between CD44 and hyaluronate induces chemoresistance in nonsmall cell lung cancer cell Cancer Lett 252 225-234 https://doi.org/10.1016/j.canlet.2006.12.025 PMID: 17276588

98. Bourguignon LY, Peyrollier K, and Xia W, et al (2008) Hyaluronan-CD44 interaction activates stem cell marker Nanog, Stat3-mediated MDR1 gene expression, and ankyrin-regulated multidrug efflux in breast and ovarian tumor cells $\mathrm{J}$ Biol Chem 283 17635-17651 https://doi.org/10.1074/jbc.M800109200 PMID: 18441325 PMCID: 2427357

99. Bourguignon LY, Spevak CC, and Wong G, et al (2009) Hyaluronan-CD44 interaction with protein kinase C€ promotes oncogenic signaling by the stem cell marker Nanog and the production of microRNA-21, leading to down-regulation of the tumor suppressor protein PDCD4, anti-apoptosis, and chemotherapy resistance in breast tumor cells J Biol Chem 284 26533-26546 https://doi.org/10.1074/jibc.M109.027466 PMID: 19633292 PMCID: 2785342

100. Chen L, Bourguignon L (2014) Hyaluronan-CD44 interaction promotes C-Jun signaling and miRNA21 expression leading to Bcl-2 expression and chemoresistance in breast cancer cells Mol Cancer 131186 https://doi.org/10.1186/1476-4598-13-52

101. Bourguignon LY (2008) Hyaluronan-mediated CD44 activation of RhoGTPase signaling and cytoskeleton function promotes tumor progression Paper presented at: Seminars in cancer biology (Elsevier)

102. Singleton PA, Bourguignon LY (2002) CD44v10 interaction with Rho-kinase (ROK) activates inositol 1, 4, 5-triphosphate (IP3) receptor-mediated Ca2+ signaling during hyaluronan (HA)-induced endothelial cell migration Cell Motil Cytoskel 53 293-316 https://doi.org/10.1002/cm.10078

103. Bourguignon LY, Wong G, and Earle C, et al (2010) Hyaluronan-CD44 interaction promotes c-Src-mediated twist signaling, microRNA-10b expression, and RhoA/RhoC up-regulation, leading to Rho-kinase-associated cytoskeleton activation and breast tumor cell invasion J Biol Chem 285 36721-36735 https://doi.org/10.1074/jbc.M110.162305 PMID: 20843787 PMCID: $\underline{2978601}$

104.Prehm P, Schumacher U (2004) Inhibition of hyaluronan export from human fibroblasts by inhibitors of multidrug resistance transporters Biochem Pharmacol 68 1401-1410 https://doi.org/10.1016/.bcp.2004.06.017

105. Jaiswal R, Johnson MS, and Pokharel D, et al (2017) Microparticles shed from multidrug resistant breast cancer cells provide a parallel survival pathway through immune evasion BMC Cancer 17104 https://doi.org/10.1186/s12885-017-3102-2 PMID: $\underline{28166767}$ PMCID: $\underline{5294826}$

106. Johnson P, Ruffell B (2009) CD44 and its role in inflammation and inflammatory diseases Inflamm Allergy Drug Target 8 208-220 https://doi.org/10.2174/187152809788680994

107. Mori T, Kitano K, and Terawaki SI, et al (2008) Structural basis for CD44 recognition by ERM proteins J Biol Chem $28329602-$ 29612 https://doi.org/10.1074/jibc.M803606200 PMID: 18753140 PMCID: 2662033 
108. Miletti-González KE, Chen S, and Muthukumaran N, et al (2005) The CD44 receptor interacts with P-glycoprotein to promote cell migration and invasion in cancer Cancer Res 65 6660-6667 https://doi.org/10.1158/0008-5472.CAN-04-3478 PMID: 16061646

109. Hong SP, Wen J, and Bang S, et al (2009) CD44-positive cells are responsible for gemcitabine resistance in pancreatic cancer cells Int J Cancer 125 2323-2331 https://doi.org/10.1002/ijc.24573 PMID: 19598259

110. Prince M, Sivanandan R, and Kaczorowski A, et al (2007) Identification of a subpopulation of cells with cancer stem cell properties in head and neck squamous cell carcinoma Proc Natl Acad Sci 104 973-978 https://doi.org/10.1073/pnas.0610117104 PMID: 17210912 PMCID: 1783424

111. Yang JM, Xu Z, and Wu H, et al (2003). Overexpression of extracellular matrix metalloproteinase inducer in multidrug resistant cancer cells1 1 US Public Health Service National Cancer Institute CA 66077 and CA 72720 Mol Cancer Res $1420-427$ PMID: 12692261

112. Ding S, Chamberlain M, and McLaren A, et al (2001) Cross-talk between signalling pathways and the multidrug resistant protein MDR-1 Br J Cancer 851175 https://doi.org/10.1054/bjoc.2001.2044 PMID: 11710832 PMCID: 2375166

113. Tang W, Chang SB, Hemler ME (2004) Links between CD147 function, glycosylation, and caveolin-1 Mol Biol Cell $154043-4050$ https://doi.org/10.1091/mbc.E04-05-0402

114. Wang WJ, Li QQ, and Xu JD, et al (2007) Interaction between CD147 and P-glycoprotein and their regulation by ubiquitination in breast cancer cells Chemotherapy 54 291-301 https://doi.org/10.1159/000151225

115. Li QQ, Wang WJ, and XU JD, et al (2007) Involvement of CD147 in regulation of multidrug resistance to P-gp substrate drugs and in vitro invasion in breast cancer cells Cancer Sci 98 1064-1069 https://doi.org/10.1111/j.1349-7006.2007.00487.x PMID: 17441962

116. Taylor PM, Woodfield RJ, and Hodgkin MN, et al (2002) Breast cancer cell-derived EMMPRIN stimulates fibroblast MMP2 release through a phospholipase A (2) and 5-lipoxygenase catalyzed pathway Oncogene 21 5765-5772 https://doi.org/10.1038/ sj.onc.1205702 PMID: 12173047

117. Gabison EE, Hoang-Xuan T, and Mauviel A, et al (2005) EMMPRIN/CD147, an MMP modulator in cancer, development and tissue repair Biochimie 87 361-368 https://doi.org/10.1016/j.biochi.2004.09.023 PMID: 15781323

118. Muramatsu T, Miyauchi T (2003) Basigin (CD147): a multifunctional transmembrane protein involved in reproduction, neural function, inflammation and tumor invasion 8(3):981-7

119. Sugie S, Mukai S, and Yamasaki K, et al (2015) Significant association of caveolin-1 and caveolin-2 with prostate cancer progression Cancer Genomic Proteomic 12 391-396

120. Demeule M, Jodoin J, and Gingras D, et al (2000) P-glycoprotein is localized in caveolae in resistant cells and in brain capillaries FEBS Lett 466 219-224 https://doi.org/10.1016/S0014-5793(00)01087-5 PMID: 10682831

121. Yang CPH, Galbiati F, and Volonté D, et al (1998) Upregulation of caveolin-1 and caveolae organelles in taxol-resistant A549 cells FEBS Lett 439 368-372 https://doi.org/10.1016/S0014-5793(98)01354-4 PMID: 9845355

122. Roussel É, Bélanger MM, Couet J (2004) G2/M blockade by paclitaxel induces caveolin-1 expression in A549 lung cancer cells: caveolin-1 as a marker of cytotoxicity Anti-cancer Drugs 15 961-967 https://doi.org/10.1097/00001813-200411000-00005 PMID: 15514565

123. Jodoin J, Demeule M, and Fenart L, et al (2003) P-glycoprotein in blood-brain barrier endothelial cells: interaction and oligomerization with caveolins J Neurochem 87 1010-1023 https://doi.org/10.1046/j.1471-4159.2003.02081.x PMID: 14622130

124. Bélanger MM, Gaudreau M, and Roussel É, et al (2004) Role of caveolin-1 in etoposide resistance development in A549 lung cancer cells Cancer Biol Ther 3 954-959 https://doi.org/10.4161/cbt.3.10.1112 
125. Barakat S, Demeule M, and Pilorget A, et al (2007) Modulation of p-glycoprotein function by caveolin-1 phosphorylation J Neurochem 101 1-8 https://doi.org/10.1111/j.1471-4159.2006.04410.x PMID: 17326770

126. Lavie Y, Fiucci G, Liscovitch M (2001) Upregulation of caveolin in multidrug resistant cancer cells: functional implications $A d v$ Drug Deliv Rev 49 317-323 https://doi.org/10.1016/S0169-409X(01)00144-2 PMID: 11551402

127. Lavie Y, Fiucci G, Liscovitch M (1998) Up-regulation of caveolae and caveolar constituents in multidrug-resistant cancer cells J Biol Chem 273 32380-32383 https://doi.org/10.1074/jbc.273.49.32380 PMID: $\underline{9829965}$

128. Fu D, Bebawy M, and Kable EP, et al (2004) Dynamic and intracellular trafficking of P-glycoprotein-EGFP fusion protein: Implications in multidrug resistance in cancer Int J Cancer 109 174-181 https://doi.org/10.1002/ijc.11659 PMID: 14750166

129. Fu D, Roufogalis BD (2007) Actin disruption inhibits endosomal traffic of P-glycoprotein-EGFP and resistance to daunorubicin accumulation Am J Physiol-Cell Physiol 292 C1543-C1552 https://doi.org/10.1152/ajpcell.00068.2006

130.Fu D, Arias IM (2012) Intracellular trafficking of P-glycoprotein Int J Biochem Cell Biol 44 461-464 https://doi.org/10.1016/j.biocel.2011.12.009 PMID: 22212176 PMCID: $\underline{3288648}$

131. Katayama K, Noguchi K, Sugimoto Y (2013) FBX015 regulates P-glycoprotein/ABCB1 expression through the ubiquitin-proteasome pathway in cancer cells Cancer Sci 104 694-702 https://doi.org/10.1111/cas.12145 PMID: 23465077

132. De Rosa MF, Sillence D, and Ackerley C, et al (2004) Role of multiple drug resistance protein 1 in neutral but not acidic glycosphingolipid biosynthesis J Biol Chem 279 7867-7876 https://doi.org/10.1074/jbc.M305645200

133. Novick P, Zerial M (1997) The diversity of Rab proteins in vesicle transport Curr Opin Cell Bio/ $9496-504$ https://doi.org/10.1016/ S0955-0674(97)80025-7 PMID: $\underline{9261061}$

134.Jordens I, Marsman M, and Kuijl C, et al (2005) Rab proteins, connecting transport and vesicle fusion Traffic 6 1070-1077 https:// doi.org/10.1111/j.1600-0854.2005.00336.x PMID: 16262719

135. Seabra MC, Mules EH, Hume AN (2002) Rab GTPases, intracellular traffic and disease Trends Mol Med 8 23-30 https://doi. org/10.1016/S1471-4914(01)02227-4 PMID: 11796263

136. Diekmann Y, Seixas E, and Gouw M, et al (2011) Thousands of rab GTPases for the cell biologist PLoS Comput Biol 7 e1002217 https://doi.org/10.1371/journal.pcbi.1002217 PMID: 22022256 PMCID: $\underline{3192815}$

137. Ullrich O, Reinsch S, and Urbé S, et al (1996) Rab11 regulates recycling through the pericentriolar recycling endosome $J$ Cell Biol 135 913-924 https://doi.org/10.1083/jcb.135.4.913 PMID: $\underline{8922376}$ PMCID: 2133374

138. Schonteich E, Wilson GM, and Burden J, et al (2008) The Rip11/Rab11-FIP5 and kinesin II complex regulates endocytic protein recycling J Cell Sci 121 3824-3833 https://doi.org/10.1242/jcs.032441 PMID: 18957512 PMCID: 4365997

139. Wakabayashi Y, Dutt $P$, and Lippincott-Schwartz J, et al (2005) Rab11a and myosin Vb are required for bile canalicular formation in WIF-B9 cells Proc Natl Acad Sci USA 102 15087-15092 https://doi.org/10.1073/pnas.0503702102 PMID: 16214890 PMCID: 1257697

140.Ferrándiz-Huertas C, Fernández-Carvajal A, Ferrer-Montiel A (2011) Rab4 interacts with the human P-glycoprotein and modulates its surface expression in multidrug resistant K562 cells Int J Cancer 128 192-205

141. Shan J, Mason JM, and Yuan L, et al (2000) Rab6c, a new member of the rab gene family, is involved in drug resistance in MCF7I AdrR cells Gene 257 67-75 https://doi.org/10.1016/S0378-1119(00)00395-4 PMID: 11054569

142.Fu D, van Dam EM, and Brymora A, et al (2007) The small GTPases Rab5 and RalA regulate intracellular traffic of P-glycoprotein Biochimica et Biophysica Acta 1773 1062-1072 https://doi.org/10.1016/j.bbamcr.2007.03.023

143.Zhang Z, Wu JY, and Hait WN, et al (2004) Regulation of the stability of P-glycoprotein by ubiquitination Mol Pharmacol 66 395-403 https://doi.org/10.1124/mol.104.001966 PMID: 15322230 
144. Mori S, Heldin CH, Claesson-Welsh L (1992) Ligand-induced polyubiquitination of the platelet-derived growth factor betareceptor J Biol Chem 267 6429-6434 PMID: 1313434

145. Kölling R, Hollenberg CP (1994) The ABC-transporter Ste6 accumulates in the plasma membrane in a ubiquitinated form in endocytosis mutants EMBO J 133261 PMID: $\underline{8045256}$ PMCID: $\underline{395222}$

146.Pickart CM, Eddins MJ (2004) Ubiquitin: structures, functions, mechanisms Biochimica et Biophysica Acta 1695 55-72 https://doi. org/10.1016/j.bbamcr.2004.09.019 PMID: 15571809

147. Greten FR, Karin M (2004) The IKK/NF-KB activation pathway-a target for prevention and treatment of cancer Cancer Lett 206 193-199 https://doi.org/10.1016/j.canlet.2003.08.029

148. Hui RC, Francis RE, and Guest SK, et al (2008) Doxorubicin activates FOXO3a to induce the expression of multidrug resistance gene ABCB1 (MDR1) in K562 leukemic cells Mol Cancer Ther 7 670-678 https://doi.org/10.1158/1535-7163.MCT-07-0397 PMID: 18347152

149. Liu M, Aneja R, and Wang H, et al (2008a) Modulation of multidrug resistance in cancer cells by the E3 ubiquitin ligase sevenin-absentia homologue $1 \mathrm{~J}$ Pathol 214 508-514 https://doi.org/10.1002/path.2312

150. Saeki M, Kurose K, and Tohkin M, et al (2008) Identification of the functional vitamin D response elements in the human MDR1 gene Biochem Pharmacol 76 531-542 https://doi.org/10.1016/j.bcp.2008.05.030

151. Liu M, Aneja R, and Wang $\mathrm{H}$, et al (2008b) Modulation of multidrug resistance in cancer cells by the E3 ubiquitin ligase sevenin-absentia homologue $1 \mathrm{~J}$ Pathol 214 508-514 https://doi.org/10.1002/path.2312

152. Guenou H, Kaabeche K, and Dufour C, et al (2006) Down-regulation of ubiquitin ligase Cbl induced by twist haploinsufficiency in Saethre-Chotzen syndrome results in increased PI3K/Akt signaling and osteoblast proliferation Am J Pathol 169 1303-1311 https://doi.org/10.2353/ajpath.2006.060102 PMID: 17003487 PMCID: 1698848

153. Riganti C, Kopecka J, and Panada E, et al (2015) The role of C/EBP- $\beta$ LIP in multidrug resistance J Natl Cancer Inst 107 djv046 https://doi.org/10.1093/jnci/djv046

154. Lindquist S, Craig E (1988) The heat-shock proteins Ann Rev Genetic 22 631-677 https://doi.org/10.1146/annurev.ge.22.120188.003215

155. McConnell JR, McAlpine SR (2013) Heat shock proteins 27, 40, and 70 as combinational and dual therapeutic cancer targets Bioorg Med Chem Lett 23 1923-1928 https://doi.org/10.1016/j.bmcl.2013.02.014 PMID: 23453837 PMCID: 3602338

156. Whitesell L, Lin NU (2012) HSP90 as a platform for the assembly of more effective cancer chemotherapy Biochimica et Biophysica Acta 1823 756-766 https://doi.org/10.1016/j.bbamcr.2011.12.006 PMID: 22222203

157. Kim HB, Lee SH, and Um JH, et al (2015) Sensitization of chemo-resistant human chronic myeloid leukemia stem-like cells to Hsp90 inhibitor by SIRT1 inhibition Int J Biol Sci 11923 https://doi.org/10.7150/ijbs.10896 PMID: 26157347 PMCID: 4495410

158. Crowell JA, Steele VE, Fay JR (2007) Targeting the AKT protein kinase for cancer chemoprevention Mol Cancer Ther 62139 2148 https://doi.org/10.1158/1535-7163.MCT-07-0120 PMID: 17699713

159. Xin Y, Yin F, and Qi S, et al (2013) Parthenolide reverses doxorubicin resistance in human lung carcinoma A549 cells by attenuating NF-KB activation and HSP70 up-regulation Toxicol Lett 221 73-82 https://doi.org/10.1016/j.toxlet.2013.06.215

160. Mannervik B, Alin P, and Guthenberg C, et al (1985) Identification of three classes of cytosolic glutathione transferase common to several mammalian species: correlation between structural data and enzymatic properties Proc Natl Acad Sci 82 7202-7206 https://doi.org/10.1073/pnas.82.21.7202 PMID: $\underline{3864155}$ PMCID: $\underline{390817}$

161.Longley D, Johnston P (2005) Molecular mechanisms of drug resistance J Pathol 205 275-292 https://doi.org/10.1002/path.1706 PMID: $\underline{15641020}$ 
162. Cullen KJ, Newkirk KA, and Schumaker LM, et al (2003) Glutathione S-transferase $\pi$ amplification is associated with cisplatin resistance in head and neck squamous cell carcinoma cell lines and primary tumors Cancer Res 63 8097-8102 PMID: 14678959

163. Sakamoto M, Kondo A, and Kawasaki K, et al (2001) Analysis of gene expression profiles associated with cisplatin resistance in human ovarian cancer cell lines and tissues using cDNA microarray Human cell 14 305-315

164. Tiirikainen M, Elonen E, and Syrjälä M, et al (1994) Flow cytometric analysis of glutathione-S-transferase-pi in acute leukemia Leukemia 8 978-984 PMID: $\underline{7516031}$

165. Arai T, Yasuda Y, and Takaya T, et al (1999) Immunohistochemical expression of glutathione transferase-pi in untreated primary non-small-cell lung cancer Cancer Detect Prevent 24 252-257

166. Sutoh I., Kohno H, and Nakashima Y, et al (2000) Concurrent expressions of metallothionein, glutathione S-transferase- $\pi$, and P-glycoprotein in colorectal cancers Dis Colon Rectum 43 221-232 https://doi.org/10.1007/BF02236987 PMID: 10696897

167. Tsuda H, Hirohashi S, and Shimosato $\mathrm{Y}$, et al (1989) Correlation between long-term survival in breast cancer patients and amplification of two putative oncogene-coamplification units: hst-1/int-2 and c-erbB-2/ear-1 Cancer Res 49 3104-3108 PMID: $\underline{2566377}$

168. Siddik ZH (2003) Cisplatin: mode of cytotoxic action and molecular basis of resistance Oncogene 22 7265-7279 https://doi. org/10.1038/sj.onc.1206933 PMID: 14576837

169. Thomas H, Coley HM (2003) Overcoming multidrug resistance in cancer: an update on the clinical strategy of inhibiting p-glycoprotein Cancer Control 10 159-159 PMID: 12712010

170. Liscovitch M, Lavie Y (2002) Cancer multidrug resistance: a review of recent drug discovery research IDrugs 5 349-355

171.Jaiswal R, Grau GER, Bebawy M (2014) Cellular communication via microparticles: role in transfer of multidrug resistance in cancer Future Oncol 10 655-669 https://doi.org/10.2217/fon.13.230 PMID: 24754595

172. He H, Dai F, and Yu L et al (2002) Identification and characterization of nine novel human small GTPases showing variable expressions in liver cancer tissues Gene Expr 10 5-6 https://doi.org/10.3727/000000002783992406

173. Shimada K, Uzawa K, and Kato M, et al (2005) Aberrant expression of RAB1A in human tongue cancer Br J Cancer 92 1915-1921 https://doi.org/10.1038/sj.bjc.6602594

174. Culine S, Honore N, and Closson V, et al (1994) A small GTP-binding protein is frequently overexpressed in peripheral blood mononuclear cells from patients with solid tumours Eur J Cancer 30 670-674 https://doi.org/10.1016/0959-8049(94)90542-8

175. Yao R, Wang Y, and Lubet RA, et al (2002) Differentially expressed genes associated with mouse lung tumor progression Oncogene 21 5814-5821 https://doi.org/10.1038/sj.onc.1205422 PMID: 12173053

176. Tan PY, Chang CW, and Chng KR, et al (2012) Integration of regulatory networks by NKX3-1 promotes androgen-dependent prostate cancer survival Mol Cell Biol 32 399-414 https://doi.org/10.1128/MCB.05958-11 PMCID: 3255774

177. Amillet JM, Ferbus D, and Real FX, et al (2006) Characterization of human Rab20 overexpressed in exocrine pancreatic carcinoma Hum Pathol 37 256-263 https://doi.org/10.1016/j.humpath.2005.10.017

178. Kotzsch M, Sieuwerts AM, and Grosser M, et al (2008) Urokinase receptor splice variant uPAR-del4/5-associated gene expression in breast cancer: identification of rab31 as an independent prognostic factor Breast Cancer Res Treat 111 229-240 https:// doi.org/10.1007/s10549-007-9782-6

179. Cheng KW, Lahad JP, and Kuo WI, et al (2004) The RAB25 small GTPase determines aggressiveness of ovarian and breast cancers Nat Med 10 1251-1256 https://doi.org/10.1038/nm1125 PMID: 15502842

180.Pellinen T, Tuomi S, and Arjonen A, et al (2008) Integrin trafficking regulated by Rab21 is necessary for cytokinesis Develop Cell 15 371-385 https://doi.org/10.1016/j.devcel.2008.08.001 